\title{
Consumers and deregulation of the electricity market in Germany
}

\author{
Lucia A. Reisch · Hans-W. Micklitz
}

Received: 15 January 2006/ Accepted: 15 July $2006 /$

Published online: 4 January 2007

(C) Springer Science+Business Media B.V. 2006

\begin{abstract}
Against the backcloth of EU regulation, this note looks at the "politics of necessity" regarding electricity provision in Germany. Electricity as a case is chosen because its provision has been undergoing a profound process of liberalisation and deregulation, and there is a considerable amount of experience with the chances and pitfalls of liberalisation in this sector. Secondly, electricity is a network industry and a natural monopoly subject to systematic market failure, which calls for regulation. The paper starts out with a closer look at the consumer as an actor in the regulation process, proposing a three-role model of the consumer as a market player, as a citizen, and as a micro-producer in households and networks. In these roles, consumers take on different social and political identities; they are affected differently by (de)regulation of essential services and have different options for reacting to quality and price issues. It then describes the legal state and the development of deregulation in the electricity sector in Germany. Selected empirical data are presented, and consumer policy implications are drawn.
\end{abstract}

Keywords deregulation · electricity market · politics of necessities · consumer policy

\section{Introduction}

Since early 2005, an increasingly heated public debate on sharply rising energy prices (i.e., electricity, gas, and oil) in Germany has put the "politics of necessities" higher

L. A. Reisch $(\bowtie)$

Department of Intercultural Communication and Management, Copenhagen Business School, Porcelænshaven 18a, 2000 Frederiksberg, Denmark

e-mail: lr.ikl@cbs.dk

Hans-W. Micklitz

Chair for German and European Private and Economic Law, University of Bamberg,

Kirschäckerstr. 39, 96052 Bamberg, Germany

e-mail: hans-w.micklitz@sowi.uni-bamberg.de 
on the political agenda. Lately, the German Monopolies and Merger Commission has asked the four largest energy providers to provide full transparency of their end-user price calculation, and the newly founded Federal Net Agency is currently auditing their net user fees. At the same time, increasing consumer resistance to the acceptance of rising prices can be witnessed, mirrored by intensified consumer lobby activism (and tentatively reacting politicians), as well as by individual consumers' payment refusal, legal actions, and claims. In some sense, energy prices have become the bread prices of the twenty-first century. Moreover, they have been depicted as a key factor in depriving private households of the purchasing power so badly needed to reach the Lisbon goals of economic growth. This point has not only been made by consumer activists, but also by the German Federal President.

While the access problems to basic goods such as energy, clean water, and public transport are doubtlessly much more profound for people in less developed countries (as shown, e.g., by the yearly UNDP Human Development Reports), the-physical or financial-exclusion of access to such basic utilities is also a relevant problem for consumers in well-off societies. In the eyes of most European consumers, the main problem with services of general interest is less the physical access, but rather the quality and the price of the services (European Commission, 2003a). "Quality" comprises the constant and reliable availability of the service, its value of benefit, its long-term security of supply-which becomes more and more shaky as the break down of the supply due to heavy snow falls in the winter of 2005/ 2006 in Germany demonstrated-as well as the protection of collective goods such as the environment. "Fair prices" mean that beyond market conditions, prices are calculated based on the principle of solidarity, so that also vulnerable consumers have access to these services independent of their income and domicile. The provision of public distributive services such as electricity is a basic function of society and significantly contributes to the quality of life. For the supply side, this is captured in the term "basic industries," for the demand side, the discussion falls under the heading "universal services" (European Commission, 2003b).

The present paper contributes to this debate. Against the backcloth of EU regulation and policy, it looks at the "politics of necessity" regarding electricity provision in Germany. Admittedly, an evaluation of the effects of liberalisation on the power of consumers could be carried out in any other Western European country with a similar market and power structure, since the development has to some extent been parallel. Electricity as a case was chosen for several reasons:

(1) Firstly, because its provision has been undergoing a profound process of liberalisation and deregulation since the late 1980s, accompanied by intense lobbying by both industry and consumers' organisations. Hence, there is a considerable amount of experience with the chances and pitfalls of liberalisation in this sector.

(2) Secondly, electricity is a network industry (European Commission, 2003b). These industries are subject to systematic market failure. The normative theory of regulation justifies state regulation with the correction of these failures. Six actors of the regulation process can be identified (Genoud, 2001, pp. 17-18): Government and parliament set the legal framework for the liberalisation; the sector specific regulator (in our case: the Federal Net Agency) monitors the regulation process and implements the regulation design; public and private suppliers offer their services both in the realm of basic services and in the 
competitive realm; private households and companies demand the services on the market; courts administer the law in case of conflicts between the actors; and the competition regulator (here: the Federal Monopolies and Merger Commission) monitors the markets.

(3) Thirdly, electricity is a (unpure) collective good with external effects of supply and use, and its supply is provided by natural monopolies with the typical problems of market concentration and power-imbalances (Abegg, 2005). According to the theory of merit goods (Musgrave, 1987), "community preferences" of merit goods are a key case for state intervention, regarding both their allocation and distribution. Hence, it can be expected that policy implications derived from the electricity case may, up to a point, be also applied to other network-based industries such as gas, telecommunication, and public transport.

The goal of the paper is to look at and comment on the process of deregulation in the German electricity sector from an explicit consumer perspective, and to draw some implications for a "politics of necessities" that deliberately encompasses the consumer interest. The aim of this note is not to analyse theoretically and empirically all the actors involved in regulation and their interplay within the respective "regulation regimes" (Grande \& Eberlein, 1999, p. 641). ${ }^{1}$ The paper starts out with a closer look at the consumer as an actor in the regulation process, proposing a three-role model of the consumer as a market player, as a citizen, and as a micro-producer in households and networks. In these roles, consumers take on different social and political identities; they are affected differently by (de)regulation of essential services and have different options for reacting to quality and price issues. It then describes the legal state and the development of the deregulation in the electricity sector. Selected empirical data are presented, and consumer policy implications are drawn.

\section{The three roles of the consumer}

In consumer policy, the term "consumer" appears in different contexts and terminologies. In consumer policy discourse, it has been proposed (Reisch, 2004) that consumers should not be conceptualised exclusively as market players, but also as citizens and producers in households performing so-called "informal work." This is in accordance with household behaviour theory (Cécora, 1991) that recognises three basic collective entities that frame consumer behaviour: enterprises, the state, and households. Empirically, consumers do not behave as fully informed, economically rational, isolated market actors - the way demand is conceptualised in neoclassical consumption theory. Rather, preferences and consumption decisions are codetermined by informal and formal institutions and networks. They are framed by-eventually countervailing-political preferences from being a citizen of a community and a state. They are steered by needs from being a member of households, of associations, and of peer groups, and supply side communication is constantly evaluated by peers and other relevant persons in communications arenas. Such more empirically valid concepts of the consumer are increasingly proposed by

${ }^{1}$ For such an attempt based on the "positive theory of regulation" see Bonde (2002), and also Cox (2001). From a legal perspective see Hellermann (2001). 
institutional, evolutionary, and behavioural economics as well as by demand-side approaches to consumer policy (OECD 2006).

\section{Consumers as market players}

As soon as people spend money for a service or product, they become consumers. Consumers are therefore, above all, defined as market players and consuming actors, representing the corresponding opposite side of producers. The opportunities for consumers to act successfully on markets depend on several factors such as:

- the focus of (EU, national) economic policy on either the demand or the supply side of the market;

- the leitbild of the consumer shared by political decision makers and the courts, i.e., the "average circumspect and comprehensible consumer" or the "unknowing weak" consumer that has to be protected (or something in between);

- national law and legally binding agreements at bilateral and multilateral levels; for instance, the right to transparent pricing in the new European energy law must be regarded as a genuine individual enforceable right;

- the quality of implementation of these laws; this depends, inter alia, on how well suppliers' market practices are monitored and how rigorously fraud is made public, e.g., through consumer watchdog schemes;

- shifts in purchasing power within the market due to unequal direct or indirect state subsidies for producers or consumers or specific technological pathways (e.g., subsidies supporting nuclear power or renewable energies);

- the symmetry or asymmetry of different market players' access to information, which in turn depends on the market structure and the transparency politics of both companies and government.

These conditions can be influenced by consumer policy, depending on the extent of consumers' organisational structuring, financial strength, and political power to fend for their interests. Yet, it has to be taken into account that the "interest of the consumer" is not a monolithic one, but an individual one, depending on the respective consumer's socio-political position and personal values and priorities. Political economy (Olson, 1971) has shown that this is a reason why consumers are difficult to organise; however, empirical evidence and more recent theoretical work (Udéhn, 1993) has proved that in fact consumers do engage in collective action. This is supported by EC Member States engaged in paving the way for bundling consumer law suits in the courts (Micklitz \& Stadler, 2005).

Market theory distinguishes between two forms of market signalling that consumers may draw upon to reveal their preferences: pro-articulation and contraarticulation (Specht, 1979, pp. 218-219). Contra-articulation is the essence of the concept of countervailing power on markets. It tells the supply side that it has violated consumer interests. The signals used to achieve this are exit, voice (Hirschman, 1970), and boycott (Friedman, 1997). Pro-articulation comprises strategies that aim at bringing about desired producer performance via positive sanctioning of suppliers' actions. The signals used are entry, confirmation, and approval (Scherhorn, 1983), as well as "buycotts" (Friedman, 1996) and prototyping (Neuner, 2000). In prototyping and buycotts, consumers are actively involved. As so-called "prosumers," they co-produce in one-way or another the desired product or service. 
The effectiveness of all those signals can be improved, if they take the form of collective consumer action (Neuner, 2000). Obviously, consumers as market players have many more options than the simple exit strategy, and those options bear elements of (sub-) political action (and hence of the "consumer-citizen").

The law strongly supports the role and function of consumers as market players in granting him or her individual and/or collective rights. This development started in Europe in the 1970s. Since the adoption of the European Single Act the European Community has taken the lead in adopting a whole set of regulations and directives which form today the core of what might be understood as European consumer law (Reich \& Micklitz, 2003; Weatherill, 2005). However, it is only in the aftermath of the liberalisation policy of the European Commission that consumers as market players have entered the electricity market.

\section{Consumers as citizens}

As citizens, consumers are the sovereigns of democracy. Since their quality of life-both individually and collectively_is strongly influenced by the availability of and access to goods and services, consumption issues do influence political preferences. Consumers as citizens express their political preferences through election and consumption decisions, and they organise themselves to fend for their interests:

- Ideally, political will is generated by citizens through discourse, inquiry, and the balancing of conflicting interest. By their votes for specific parliamentary representatives, citizens give orientation to the development of legal frameworks governing the market and their own role as consumers within that market. Upcoming elections have lately made governments more responsive to consumers' critique of energy prices.

- Through their purchasing decisions, they influence market and living conditions, including the protection of human rights and the environment, in their own countries and elsewhere. Consumption decisions made by consumer-citizens are not exclusively based on market-related interests, but also on common welfare, environmental, and social values. Consumers as citizens are interested not only in the quality of the product or service in the conventional sense ("product quality"), but also in the ethical quality of the process of production and provision ("process quality"). This approach to consumption has been termed "political consumption" (Micheletti, 2003).

- Individually and collectively, consumers exercise "exit and voice" (Hirschman, 1970). They organise themselves as members of civil society in order to promote consumer-related interests (e.g., consumer organisations, boycotts, buycotts, and campaigns). The law recognises the right of consumers to organise themselves. In so far, Article 153 EU Treaty reiterates what can be taken for granted in the Member States. However, the factual possibilities for consumers to fend collectively for their interests, are limited, mostly due to the lack of resources. The growing political resistance against energy prices demonstrates that consumers are making use of their right to organise themselves. Liberalisation of the energy market and formation of citizen groups seem to go hand in hand. In the UK, so-called consumer watchdogs take a hard look at the degree to which liberalisation produces consumer benefits, in terms of competitive energy prices (vzbv, 2005a, b). 
Consumers as producers

Consumers are members of networks and households where they do informal work (i.e., work without payment and contract). In so doing, they are also producers of highly relevant goods (e.g., family meals, subsistence farming) and services (e.g., caring, education, mutual help in neighbourhoods). In economics, informal work is seen as belonging to the so-called "informal sector" as opposed to the "formal sector" of the economy (i.e., with formal employment and payment) (Cécora, 1991). The former is less visible since its immaterial and material contributions generated for society are not adequately put on record; they are, for instance, not included in the GDP. However, informal work adds significantly to the quality of life, and many activities that are coined "consumption" are really household production. These activities are highly productive, not destructive. The formal and informal sectors are interdependent: The market often externalises its transaction costs into private households - into housework and family care, and into consumers' so-called free time. To a large extent, work required for information, coordination, storage, waste management, organisation, and transportation takes place in households. Moreover, the formal sector tends to outsource less productive work (such as caring) to the informal sector.

Households also mobilise around the provision of basic goods and essential services if the quality and/or price of provision does not meet their expectations. Through collective action (Olson, 1971), they also co-produce goods and services. The self-provision can take on forms of public-private partnerships or similar intermediate forms of co-production, but sometimes even of full self-provision. For instance, one Black Forest community has provided its own electricity grid with nuclear energy-free power since the 1990s. As a result of the Chernobyl reactor fallout in 1986, the action group "Parents for a Nuclear-free Future" ran competitions to save energy and unsuccessfully approached the town's electricity provider. After 13 years, two town referendums, and a successful nationwide campaign to raise funds, the "Schönauer Electricity Rebels" became the first German community to buy back their old power grid. They started to produce the energy their town needed by building block heating stations and installing solar panels. What they could not produce themselves, they bought. In 1999, Elektrizitätswerke Schönau ${ }^{2}$ went national; a year after the German electricity market was liberalised (Graichen 2003; Neuner, 2000). Today, the initiative heads one of the largest of Germany's half dozen "green" electricity companies that attract together between 5 and $10 \%$ of customers. They still perceive themselves as a political energy organisation, not a commercial enterprise.

\section{Deregulation and liberalisation of necessities}

Interest in the deregulation of infrastructure increased during the last two decades of the twentieth century, when many countries worldwide turned to private companies to build and operate infrastructure and utility services. In the 1980s Britain was a leader, selling off its telephone, electricity, gas, water, and railway companies in the hope that the private sector could provide better service at lower cost. In the 1990s,

\footnotetext{
2 www.ews-schoenau.de.

算 Springer
} 
many other countries (including the EU) followed suit (Hodge, 2000). Yet, by the first years of the twenty-first century enthusiasm for private utilities waned (Von Weizsäcker, Young, \& Finger, 2005), and the pace of privatisation slowed. Many governments faced growing popular resistance to proposals to privatise the utilities that still remained in public hands. Consumers were increasingly sceptical that the tariffs they were being charged were fair and the service adequate.

Liberalisation, i.e., the introduction of competition into parts of infrastructure services, has been much more significant as a means of privatisation than asset sales (Finger, 2005). It is a form of deregulation because it requires changing the infrastructure's competition rules so that competition can occur. Competition can take the form of either "competition in the market," where different suppliers compete for customers, or "competition for the market," where monopoly rights for a defined set of services, geographical area, and time period are put up for tender. Deregulation of utility industries affects sectors that are "natural monopolies": They involve heavy technologies and require substantial durable and immobile investments in establishing networks such as electricity grids. Moreover, suppliers usually benefit from large economies of scale. Both aspects present high barriers to market entry. Solutions to such infrastructural monopolies can be arrayed along a continuum according to the relative roles that markets and politics play in determining infrastructure prices and service quality. Along the continuum from markets to politics, the basis for commitment gradually shifts from commercial contracts and courts to specialised regulatory institutions, and finally to the broader social and political institutions that shape public policy (Gómez-Ibáñez, 2003a, pp. 11-12).Liberalisation often requires unbundling, i.e., splitting different stages of service delivery into different organisations, so that the parts suitable for exposure to competition are separate from the non-competitive (monopoly) elements. The costs and benefits of unbundling are different among the services (Gómez-Ibáñez, 2003b).

As highlighted above, utility industries are sectors that are critical for quality of life and consumer welfare in general since they frame the possibilities for social participation and provide the basic infrastructure for daily life, both in the formal and informal sector. Since they are essential to modern life and because infrastructure has elements of monopoly, governments usually feel compelled to regulate the prices and quality of infrastructure services. Genoud (2003) depicts two types of regulation motives: "first order economic regulation" (i.e., fair competition, open access to networks, economic efficiency) and "second order socio-political regulation" (i.e., securing social basic needs).

Deregulation has the potential to increase competition and to afford consumers many benefits, in particular those derived from advantage of price and diversity of choice (Schulze, 2003). Yet, consumers will only profit from deregulation and private competition

- if they have the competence to take on the called-for "consumer-responsibility," when the state shifts from "providing" to "enabling";

- if markets (i.e., prices, qualities) are transparent and information costs are affordable;

- and if the state controls fraud, misuse of market power, and supplier misbehaviour. 
The political instruments of deregulation are "soft instruments" such as consumer education and consumer advice to increase consumer competence and make consumers more critical consumers, but also "hard instruments" such as competition law, and market incentives or (re-)regulation to foster competition and control market power. ${ }^{3}$ In Germany and other EU countries, the main barrier to more competition is the overprized net user-fees which amount, e.g., in Germany, to about $30-40 \%$ of the electricity price. Only recently has the consumer viewpoint entered EU regulation and politics. The Communication on Services of General Interest ${ }^{4}$ adopted by the European Commission in 2000 recognises that the principal needs of consumers are a guarantee of universal access, high quality, and affordability. In order to meet these needs, a number of principles have been identified, including:

- a clear definition of basic obligations to ensure good quality service provision, high levels of public health, and physical safety of services;

- full transparency, e.g., on tarification, terms and conditions of contracts, choice, and financing of providers;

- choice of service and of supplier with effective competition between suppliers; the provision of regulatory bodies independent of operators, and redress mechanisms for complaint handling and dispute settlement.

Political solutions regarding the degree to which natural monopolies or simply state governed services can be deregulated and markets be established must be found sector by sector. In the energy sector, however, there seems to be an overall agreement within the European Community that the market shall prevail over "natural" state monopolies. In so far, the European Commission steadily continues its liberalisation policy. Liberalisation in the electricity sector permits only "outside" providers to participate in the national market if the competing company has its own network in the sectors or can use the network that already exists. Therefore, new providers must be given the possibility to access the network in a manner that is not discriminatory, i.e., by establishing fair economic and technical terms of access to the network for all companies.

The policy pursued by the European Commission is geared precisely towards this objective. It ignores, however, to a large extent the role and function private consumers might and could play in the liberalisation process and leaves the task of cushioning the impact of liberalisation in terms of consumer policy up to the Member States. In theory, the EC rules leave much leeway for the Member States to take the role and function of consumers more fully into consideration. In practice, however, the Member States remain quite reluctant to safeguard consumers'

\footnotetext{
3 "Market power" is usually defined as the degree to which a company can raise the prices for its services above its costs without losing too many sales. Two conditions are necessary for a firm to have market power: (1) The presence of some type of market entry barrier (e.g., patent protections; brand loyalty; large economies of scale; durable and immobile investments such as gas grids, water pipes, or electricity networks) that prevent newcomers from entering the market; (2) few close substitutes to the service to avoid "exit" strategies by customers.

${ }^{4}$ Communication from the Commission-Services of general interest (SGI) in Europe (COM/2000/ 0580 final). In 2001, the Commission adopted a Report on SGI that announced new measures to increase legal certainty and transparency in the application of state aid rules to the funding of SGI, and the setting up of a system of evaluation of the performances of such services. In May 2003, the Commission adopted a Green Paper on SGI (COM 2003/270 final) which elaborates on the EU consumer policy approach towards SGI.
} 
interests. If they continue this policy, the European Commission could come up with a new round of directives in which the role and function of consumers in liberalised markets is strengthened.

The following case study contributes to the analysis of whether and how a deliberate consumer-oriented perspective on the policies of necessity can shed fresh light on the debate. Regarding consumers not predominantly as market participants, but also as consumer-citizens and co-producers, might lead to a different, demandside policy approach to make the energy market work for all.

\section{The case of the German electricity sector}

Stages of liberalisation of the electricity market

In most European countries, the electricity market was previously characterised by public monopolies. All the stages required to supply the end-consumer (i.e., production, purchasing, transport, distribution) were bundled in a few hands, thus forming a so-called "vertical value-added chain." New suppliers could not enter the market since the monopolies in place prevented access to the existing network. In 1988, the European Commission drafted a three-stage plan to establish a European Energy Market. Stage 1 was intended to bring about more transparency, while Stage 2 was designed to advance liberalisation, leading to a final Stage 3 in which the distortions of competition that still existed should be eliminated.

The first step towards creating transparent, non-discriminatory conditions for the transportation of electricity was the Transit Directive concerning large mains enacted in $1991 .^{5}$ Yet, it was binding only for the network operators named in the directive. The possibility of introducing open network access ${ }^{6}$ was discussed immediately after adoption of the Transit Directive. However, it was realised only by Directive 96/92/ $E C{ }^{7}$ which was to be implemented by 19 February 1999 . The objective was to establish a single electricity market by intensifying electricity exchanges. Chapter VII of the directive left national legislators the choice between regulated network access or contractually based (negotiated) network access. While, in the case of negotiated network access, "the electricity supply company and the registered customers inside and outside the network area can negotiate network access to enable them to conclude supply contracts among each other on the basis of voluntary commercial agreements, ", regulated network access is a network access system "through which the registered customers are granted a right to network access on the basis of published scales of charges for the use of the transmission and distribution systems, with such right of access at least equivalent to the corresponding conditions for the other access systems referred to in this chapter."9 Germany chose to go the way of negotiated network access which turned out to be a failure as the parties

\footnotetext{
${ }^{5}$ Council Directive 90/547/EEC of 29.10 .1990 on the transit of long-distance electricity supplies via large networks official journal EC 313, 13.11.1990, 30.

6 Third Party Access.

${ }^{7}$ European Parliament and Council Directive 96/92/EC of 19 December 1996, Official Journal EC L 27, 31.01.1997, 20.

${ }^{8}$ Article 17 I of Directive 96/92/EC.

9 Article 17 IV of Directive 96/92/EC.
} 
could not agree on easy access conditions. This loophole was closed by Directive 2003/54/EC ${ }^{10}$ (Acceleration Directive) on common rules for the single electricity market. This directive, which was to be implemented into national law by 1st July 2004 - but which in fact has only been implemented as of 1st August 2005-sought to completely open the market for private consumers by the year 2007. According to Article 20 (third-party access) Member States are now obliged to guarantee "the introduction of a system for third-party access to the transmission and distribution networks based on published scales of charges." Regulation 1228/03 on Network Access Conditions for Transitional Electricity Exchanges ${ }^{11}$ adopted on 4th August 2003 aims at setting out fair rules for transnational electricity and establishes a compensatory mechanism for transnational electricity flows. ${ }^{12}$

The strong emphasis on network access demonstrates that consumers are primarily seen as those who should benefit from deregulated competitive markets. It took until 2003, the realisation of Stage 3, before the EC discovered "customers" as market players - end-users are customers "who purchase electricity for their own use."13 Their position in the market is strengthened. According to Article 3 (5) Member States shall ensure that the customer is able to switch to a new supplier, free of charge as Annex A makes clear. This, however, remains the sole outspoken right granted to customers. Taken all the dispersed rulings in the Directive together one might identify a set of consumer rights (Rott, 2005): the right to have access to energy supply and the right to choice and transparency; the right to affordable energy; the right to good quality; and the right to claim that the service is provided without interruption. The Directive does not contain rules on collective rights.

There are very few signs in the European energy law, which might be read so as to identify the consumer as citizen. Chapter $\mathrm{II}^{14}$ and Article $3^{15}$ deal with special provisions concerning the environment and customers. The revised Article 3 (1) of Directive 2003/54/EC stipulates that the establishment "of a competition-oriented, secure and sustainable electricity market in ecological terms" $" 16$ should be pursued. The rather vague obligation of the Member States to encourage consumer representation might at least pave the way for introducing a citizen perspective into the legal edifice.

Germany implemented the requirements of Directive 2003/54/EC by way of amendments to the Energy Industry Act (Energiewirtschaftsgesetz) that came into force on 1st July 2005. Like its European counterpart the implementing rules focus on network access, unbundling and setting a workable competition into order. Whilst there would have been leeway to upgrade the role of the consumer according to the set of identified EC rights, she has not even able to play an active part in the electricity market. This can overtly be demonstrated by the lack of appropriate collective remedies. The adopted version does no longer provide for the recovery of

\footnotetext{
${ }^{10}$ European Parliament and Council Directive 2003/54/EC on common rules for the single electricity market and rescission of Directive 96/92/EC.

${ }^{11}$ European Parliament and Council Regulation (EC) no. 1228/2003 of 26 June 2003 on network access conditions for transnational electricity exchanges, Official Journal no. L 176 of 15/07/2003 p. 1.

12 Regulation 1228/2003 Article 1 (Object and area of application).

13 Directive 2003/54/EC Chapter I, Article 2, No. 9.

${ }^{14}$ Directive 2003/54/EC Chapter II "General provisions for the organisation of the sector."

15 Directive 2003/54/EC Article 3 "Public Service Obligation and Consumer Protection."

16 Directive 2003/54/EC Chapter II, Article 3, Part I.

管 Springer
} 
ill-gotten gains, as has been foreseen in earlier drafts of the law. Such a means of collective redress would have allowed consumer organisations to skim off profits from anyone wilfully committing an infringement within the meaning of the Act and obtaining an economic advantage through such infringement to the detriment of a large number of injured parties.

However, the strong impact on environmental issues ended up in an obligation to make energy sources (coal, natural gas, nuclear power, renewable energies) transparent, i.e., to list them on the bills and advertising materials in order to enable consumers to recognise the origin of the electricity supplied and hence opt for environmentally conscious choices; furthermore an obligation to state how the price has been calculated. ${ }^{17}$ The rules include certainly a societal dimension. However, there was no willingness in the legislative process to give consumer organisations a position similar to the British "Watchdogs" (Müller, 2005). In the British system, statutory regulations concerning access conditions are combined with the institutional regulation of safeguarding consumer interests. This is based on the conviction that liberalisation of utilities has to be accompanied by a "robust champion of consumers' interest" (Blades, 2005, p. 51), a consumer body as part of the overall regulatory framework to represent the interest of consumers to companies, to the regulator, and to the government. Today, the institution of "Consumer Watchdogs" exists in all regulated market areas in Great Britain. The aim of this institution is to keep a balance between competition and consumer protection. The "Consumer Watchdogs" are funded from charges levied on the companies operating on the market (Asher, 2005; Blades, 2005). The British experience with the role of consumer representation in the liberalisation process of the electricity sector is captured in a recent report by the British Department of Trade and Industry (DTI, 2005). With some limitations, the scheme works comparatively well, and liberalisation has significantly increased efficiency of the industry and has provided better prices and services for consumers. However, the watchdog scheme is not without problems, and the report wonders whether, in the longer term, the use of ombudsmen schemes could help provide the necessary incentive for companies to deal with their own complaints effectively and hereby disburden some of the Watchdogs. ${ }^{18}$

The electricity market

\section{Electricity supply}

Fossil fuels (i.e., coal, oil, natural gas) are still the most important energy carriers in the EU (VDEW 2004). This holds also true for Germany, although there has been a quite dynamic increase in renewable energies that account for more than $10 \%$ of the power supply today. There are about 900 electricity companies on the market, which represents the largest diversity of electricity providers in the EU. However, $80 \%$ of the electricity used in Germany is produced by only four large conglomerates: ENBW, Vattenfall Europe, RWE, and E.ON. This oligopoly controls more than

\footnotetext{
${ }^{17}$ In earlier drafts of the Law, the labelling requirements for suppliers also included the CO2Emissions in the respective electricity production process.

${ }^{18}$ Energywatch was devoting $41 \%$ of its budget to handling complaints-a rather unfair burden, that the companies themselves should be handling so that resources could be used by the consumer bodies in other more productive ways (Blades, 2005, p. 54).
} 
four fifths of power plant capacities and $100 \%$ of the high-tension power line net. This oligopolistic structure of supply - the result of a governmentally permitted wave of mergers and acquisitions-means that the suppliers can more or less dictate prices, as long as there is no strong regulatory body. Only lately, and only in a few cases, have Federal States' Ministries intervened in the suppliers' price politics.

As of 1st August 2005, a Federal Net Agency (Bundesnetzagentur) has been installed with the mandate to control the prices for system usage of the network-based services, viz., energy and railways. Price increases for system usage will have to be approved by the agency. Moreover, both consumers and commercial users will have the right to lodge complaints about forcing up of prices by suppliers. However, critical voices point to the disturbing fact that the agency has been deprived of some of its most influential instruments for controlling market power, and that some of its duties have been put under the supervision of the industry-friendly Ministry of Economics and Technology. In fact, effective lobbying of the four dominating conglomerates of the energy industry has reduced consumers' rights to information and participation to a minimum.

In addition to the national suppliers, there are also foreign suppliers on the German electricity market. They either compete through their own subsidiaries (e.g., Vattenfall) or they acquire shares in German electricity suppliers (e.g., the French company Veolia, the European market leader for fresh water provision, has a $74.9 \%$ holding in the Stadtwerke Görlitz). On the other hand, the two large German companies E.ON and RWE have successful British daughter companies with 12 and $11 \%$ of the market share, respectively. Electricity is traded within Europe. In fact, Germany is a transit country for electricity exchanges. Both imports and exports are high while the net balance is almost even (VDEW, 2004).

\section{Electricity prices}

The regulator's primary aim of the liberalisation of the electricity market was to decrease electricity prices, to ease enterprises' and consumers' financial burden, and hereby to stimulate European economy. Repeatedly, high energy prices have been blamed for being a key barrier to economic upswing (e.g. vzbv, 2005a). Initially, between 1996 and 2000, when the liberalisation process started, prices decreased for both, private end consumers and industry. However, since 2001, prices have increased again. Today, German private consumers and industries are facing the highest electricity prices in Europe (followed by Italy, Belgium, Luxembourg, and Portugal). Moreover, end-user prices today are only $0.5 \%$ below pre-liberalisation prices (Growitsch \& Müsgens, 2005). On the contrary, British electricity prices are about $50 \%$ lower than those of these countries, mainly due to $50 \%$ lower prices for system usage.

According to market experts, energy prices in Germany are not cost-based, but rather depend on the margins that can be pushed through on the market, the major leverage being the prices for system usage. Even conservative sources estimate that private households have therefore spent five billion Euros more than necessary for electricity in 2004. The high profitability of the large suppliers and an estimated average return on equity of more than $30 \%$ support this view (vzbv, 2005b). In the eyes of consumer organisations (e.g., The German Association of Energy Users) as well as of industry associations, the four main conglomerates have regained their 
pre-liberalisation market power and are "plundering" consumers and enterprises in order to maximise the return on their investment. Indeed, the four major suppliers hardly compete on the market, which results in artificially high prices at the German Electricity Exchange (EEX). The four oligopolists are also the main actors at the EEX futures market where wholesale prices are determined. Indeed, the high prices today are mostly due to increased wholesale prices, not production prices (Growitsch \& Müsgens, 2005). Yet, politics lacks the concepts to bring new competitors on the market.

The suppliers, however, argue that rising prices are due to high import prices of resources (increased oil price), (eco-)taxes, and levies from the support programme for renewable energies, costs for unnecessary bureaucratic obligations, high investments costs in the network infrastructure as well as to expensive but obligatory emission certificates. Yet, the "ecotax" counts de facto only for a small percentage of the energy price, and the emission certificates were given by the state to the suppliers practically for free. In fact, the costs for the renewable energies subsidies amount only to $2.8 \%$ of the end-user price of electricity.

In a nutshell: There is a common understanding outside the energy industry that the liberalisation of the electricity sector has failed so far. An oligopoly reigns on the market, unbundling has hardly taken place, and energy prices are high and still rising. Whether the expectations that are pinned on the new Federal Net Agency will be fulfilled, is an open question. At present, the instruments to hand are not promising, and first evaluations are not positive (Müller, 2006). Hence, in the year to come, the agency plans to implement a new instrument of "incentive regulation" designed to force profiteering suppliers to lower their prices. Doubtlessly, consumer policy advocates will watch the performance of the institution closely.

\section{Implications}

Since the late 1980s, significant changes towards a liberal European market have been made in the electricity sector. In Germany, Belgium, Italy, the Netherlands, Spain, and the United Kingdom liberalisation of the electricity markets is underway or has been achieved already. While particularly in the UK many consumers have switched energy providers, this is not the case in most European countries. In Germany, only $5 \%$ of the households have switched suppliers. One reason is that consumers often fear disconnection-a rather unlikely event, in fact. Inactive consumers, however, do not contribute to a flexible and workable market. The theory of markets shows that if there is no critical mass of consumers that chooses the exit strategy, and if too many consumers are loyal to their providers (Hirschman, 1970), the signal is too weak to bring about change towards more transparency, lower prices, and better service of supply. Moreover, only a few newcomers as providers have entered the market, among them only very few providers from abroad. In fact, energy markets in the EU remain largely national, and the Single Market is still fragmented.

From a consumer perspective, the European policy as codified in the directives and regulations has not managed to make private consumers the beneficiaries of liberalised markets, and the objective of creating competitive markets has not been 
achieved (Heilemann \& Hillebrand, 2002). ${ }^{19}$ As sketched in this paper, the main barriers to more consumer benefit can be summarised as follows:

- long-term contracts and agreements between dominating suppliers;

- incomplete unbundling of net owners and service providers;

- prohibitive economic barriers for newcomers to enter the market at fair and nondiscriminatory conditions;

- lack of foreign competitors and of new entrants in general;

- insufficient transparency of the sources of the energy in a substantial number of Member States;

- lack of transparent information on fees and environmental issues for private consumers;

- weak and understaffed national regulatory agencies in most Member States.

The second and the third set of Directives on electricity and gas were mostly meant to overcome these hurdles. Now, the implementation of the directives, as far as they have been adopted, is underway in the Member States. The European Commission has provided much leeway to the Member States to give shape to the role and function of consumers on liberalised markets seriously into account. Due the lack of a clearcut EC policy this task lies in the hands of the Member States. From the consumers' viewpoint, the latest amendment of the German Energy Industry Act remains deficient both with regard to consumer protection and environmental issues: ${ }^{20}$

- Most importantly, the consumer right to exert "voice" has not been taken seriously since the action for the recovery of ill-gotten gains against providers has been discarded in the national law; yet, only few individual consumers will be able to bear the costs of private legal actions.

- The consumer right to information has been cut with reducing supplier's labelling obligation to a minimum (e.g. no statement of $\mathrm{CO}_{2}$-emissions of energy source); yet, only informed consumers can make informed choices-the base of thriving and working markets.

- The right to participate in procedures, the involvement of consumers in decisionmaking process by the regulatory authority, and the involvement of consumer organisations as monitoring actors, is a potential that has not been exploited; most Member State rules are rather weak and need urgently to be strengthened to allow the participation of consumer organisations. A Community input is heavily needed.

- The consumer right to "exit" cannot be effective in monopolistic or oligopolistic markets. To date, there is even less competition on the electricity market than before the deregulation process. Unbundling has not been completed and prices reflect the monopolistic structure. Moreover, there are no clear rules when private households change providers.A "politics of necessities" in the interest of consumers will have to start from these basic rights: Consumers as market actors can only act on their role as market sovereign if they can determine their energy

19 The "Energy Package" still remains to be implemented in as many as 11 Member States.

${ }^{20}$ In contrast, from an energy-industry viewpoint, the aim of "lean regulation" has been accomplished and additional burdens placed upon companies through bureaucracy and state interference-and hence an increase in price-could successfully be avoided (see VDEW on his website www.strom.de). 
demand as regards products and processes. Exit and voice, the tools of the consumer as consumer-citizen, need both, working competition and market transparency. Finally, consumers should increasingly be regarded as co-producers of energy - and the respective infrastructure should be provided.

Consumer activists (e.g., Müller, 2004) call for the following issues to be put on the policy agenda of EU and national politics of necessities:

(4) Most importantly, the introduction of minimum standards for the structuring of contractual relations between private consumers and the energy supply companies. So far, Directive 93/13/EC on unfair terms in consumer contracts apply as far as liberalisation has been reached. However, one of the bigger problems is price transparency and consumption transparency. Here, much more has to be done at the European level.

(5) The provision of appropriate individual and collective means of legal redress to eliminate market deficiencies and, where applicable, compensation. This is not addressed under the directives. The European Commission has published a Green Paper on private enforcement in competition matters. However, it is not sure whether and to what extent the markets under review here would fall under the scope of a future legislative proposal, if any, in that respect, or whether alternative legal instruments would apply. In any case, this issue remains to be addressed.

(6) The strengthening of institutionalised consumer rights as a countervailing power to the supply side. The German Federal Association of Consumer Organisations (vzbv, 2005b) calls for: a panel for consumer affairs within the regulatory body; a right to file class action suits for consumer organisations within the regulatory body for all customer affairs (also in cases of incorrect gas or electricity bills); an obligation for energy providers to install effective complaint management systems; the institutionalisation of an arbitration board for consumer complaints carried by the consumer associations.

(7) Implementation of clear and transparent rules regarding changing position of personnel between energy providers, politics, and regulatory body.

The above-mentioned DTI report (DTI, 2005, pp. 119-127) develops a detailed "regulatory framework that works well for all consumers." The recommendations are based on three aspects: empowered consumers, strategic partnerships with government and regulators, and constructive but challenging relationship with suppliers. The instruments called for are transparency of price and quality, (re-)regulation of the networks, and representation of consumer interests in the respective bodies and/or via specialised consumer organisations. While steps are taken towards more transparency and (re-)regulation, both the necessary legal and financial base for effective monitoring and consumer representation is still missing in most Member States to date. Hence, the programme outlined in the DTI report could act as a blueprint for consumer-friendly European deregulation processes. 


\section{References}

Abegg, C. (2005). Liberalisierung von Netzsektoren. Auswirkungen auf die Unternehmen im Schweizer Alpenraum. Zūrich: VDF.

Asher, A. (2005). The watchdogs: Energywatch. In: e. V. vzbv (Ed.), Consumer Watchdogs-eine Option für die liberalisierten Märkte in Deutschland? (pp. 66-71). Berlin: Berliner Wissenschafts.

Blades, E. (2005). Representing consumers' interests in the liberalised gas and electricity markets-the British model. In e. V. vzbv (Eds.), Consumer Watchdogs-eine Option für die liberalisierten Märkte in Deutschland? (pp. 50-55). Berlin: Berliner Wissenschafts.

Bonde, B. (2002). Deregulierung und Wettbewerb in der Elektrizitätswirtschaft. Eine Untersuchung der politischen Ökonomie der Liberalisierung im internationalen Vergleich. Frankfurt/Main: Peter Lang.

Cécora, J. (1991). The role of "informal" activity in household economic behaviour. Berlin: Duncker \& Humblot.

Cox, H. (2001). Zur Organisation der Daseinsvorsorge in Deutschland. Stand und Entwicklungstendenzen in europäischer Perspektive. In: Schader-Stiftung (Eds.), Die Zukunft der Daseinsvorsorge. Öffentliche Unternehmen im Wettbewerb. Gesellschaftswissenschaften-Praxis (pp. 25-40). Darmstadt: Schader-Stiftung.

Department of Trade and Industry (DTI) and HM Treasury (2005). Consumer representation in regulated industries. A report, July 2004. In: e.V. vzbv (Ed.), Consumer Watchdogseine Option für die liberalisierten Märkte in Deutschland? pp. 83-132. Berlin: Berliner Wissenschafts.

European Commission (2003a). European consumers and services of general interest. Qualitative study in the 15 Member States and the 10 future Member States acceding to the European Union in 2004. Versailles: European Commission.

European Commission (2003b). Green paper on services of general interest. COM (2003) 270. Brussels: Commission of the European Communities.

Finger, M. (2005). Privatization of the infrastructures. In E. U. v. Weizsäcker, O. R. Young \& M. Finger (Eds.), Limits to privatization. How to avoid too much of a good thing - a report to the club of Rome (pp. 235-239). London: Earthscan.

Friedman, M. (1996). A positive approach to organized consumer action: The "buycott" as an alternative to the boycott. Journal of Consumer Policy, 19, 439-451.

Friedman, M. (1997). Boycotts. In: S. Brobeck (Ed.), Encyclopaedia of the consumer movement (pp. 68-69). Santa Barbara: ABC-Clio.

Genoud, C. (2001). Privatization and regulation: The case of European electricity. Cahier de l'IDHEAP no 196. Chavannes-Lausanne: IDHEAP.

Genoud, C. (2003). Regulation as a game: The role of independent regulatory agencies in the regulatory press. London: School of Economics and Political Sciences.

Gómez-Ibáñez, J. A. (2003a). Monopoly as a contracting problem. In: J. A. Gómez-Ibáñez (Ed.), Regulating infrastructure. Monopoly, contracts, and discretion (pp. 1-17). Cambridge: Harvard University Press.

Gómez-Ibáñez, J. A. (2003b). The prospects for unbundling. In J. A. Gómez-Ibáñez (Eds.), Regulating infrastructure. Monopoly, contracts, and discretion (pp. 326-339). Cambridge: Harvard University Press.

Graichen, P. (2003). Kommunale Energiepolitik und die Umweltbewegung. Eine Public-ChoiceAnalyse der "Stromrebellen" von Schönau. Frankfurt/Main: Campus.

Grande, E., \& Eberlein, B. (1999). Der Aufstieg des Regulierungsstaates im Infrastrukturbereich. Zur Transformation der politischen Ökonomie der Bundesrepublik Deutschland. In: R. Czada \& H. Wollmann (Eds.), Von der Bonner zu Berliner Republik. 10 Jahre Deutsche Einheit. Leviathan Special Issue 19/1999 (pp. 631-650). Wiesbaden: Westdeutscher.

Growitsch, C., \& Müsgens, F. (2005). Die Liberalisierung des deutschen Strommarktes-ein Erfolgsmodell? Wirtschaft und Wettbewerb, 11(12), 383-387.

Heilemann, U., \& Hillebrand, B. (2002). Liberalisierung der Strom- und Gasmärkte. Eine erste Bilanz. In: H. Berg (Ed.), Deregulierung und Privatisierung. Gewolltes-Erreichtes-Versäumtes. Schriften des Vereins für Sozialpolitik (Vol. 287, pp. 29-57). Berlin: Duncker \& Humblot.

Hellermann, J. (2001). Daseinsvorsorge im europäischen Vergleich. Zur Eigenart des bundesdeutschen Systems gemeinwohlorientierter Dienstleistungen im Vergleich mit den Strukturen in anderen europäischen Staaten und unter den Vorgaben des europäischen Gemeinschaftsrechts. In: Schader-Stiftung (Eds.), Die Zukunft der Daseinsvorsorge. Öffentliche Unternehmen im Wettbewerb. Gesellschaftswissenschaften-Praxis (pp. 78-100). Darmstadt: Schader-Stiftung. 
Hirschman, A. O. (1970). Exit, voice, and loyalty: Responses to decline in firms, organizations, and states. Cambridge: Harvard University Press.

Hodge, G. A. (2000). Privatization. An international review of performance. Boulder: Westview.

Micheletti, M. (2003). Political virtue and shopping: Individuals, consumerism, and collective action. New York: Palgrave MacMillan.

Micklitz, H.-W., \& Stadler, A. (2005). Das Verbandsklagerecht in der Informations- und Dienstleistungsgesellschaft. Münster: Landwirtschaftsverlag.

Müller, E. (2004). Verbraucherschutz und Deregulierung. Wirtschaft und Verwaltung, 2, 65-88.

Müller, E. (2005). Consumer Watchdogs-eine Option für die liberalisierten Märkte in Deutschland? In e. V. vzbv (Eds.), Consumer Watchdogs_eine Option für die liberalisierten Märkte in Deutschland? (pp. 13-16). Berlin: Berliner Wissenschafts.

Müller, E. (2006). Entwicklung der Strom- und Gaspreise vor dem Hintergrund der Arbeit der Bundesnetzagentur. Paper presented at the 7th Berlin Energy Days, 3rd May 2006. Berlin: vzbv.

Musgrave, R. A. (1987). Merit goods. In M. Milgate \& P. Newman (Eds.), The new Palgrave. A dictionary of economics (pp. 452-453). London: MacMillan.

Neuner, M. (2000). Collective prototyping: A consumer policy strategy to encourage ecological marketing. Journal of Consumer Policy, 23, 153-175.

OECD-Organisation for Economic Co-operation and Development. (2006). Roundtable on demand-side economics for consumer policy. Jeju Islands, Korea, March 2006. Draft Summary Report. DSTI/CP(2006)3. Paris: OECD.

Olson, M. (1971). The logic of collective action. Public goods and the theory of groups. Cambridge: Harvard University Press.

Reich, N., \& Micklitz, H.-W. (2003). Europäisches Verbraucherrecht (3rd ed.). Baden-Baden: Nomos.

Reisch, L. (2004). Principles and visions of a new consumer policy. Journal of Consumer Policy, 27, $1-42$.

Rott, P. (2005). A new social contract law for public services?-Consequences from regulation of services of general economic interest in the EC. European Review of Private Law, 1, 323-345.

Scherhorn, G. (1983). Die Funktionsfähigkeit von Konsumgütermärkten. In: M. Irle (Ed.), Marktpsychologie als Sozialwissenschaft. Enzyklopädie der Psychologie, Series III (Vol. 4, pp. 45-150). Göttingen: Hogrefe.

Schulze, A. (2003). Liberalisierung und Re-Regulierung von Netzindustrien. Ordnungspolitisches Paradoxon oder wettbewerbsökonomische Notwendigkeit? Volkswirtschaftliche Diskussionsbeiträge, Nr. 53. Potsdam: University of Potsdam.

Specht, G. (1979). Die Macht aktiver Konsumenten. Aktive Einflussnahme von Konsumenten auf das Marketing privater Konsumgüteranbieter unter wirkungsorientiertem Aspekt. Stuttgart: Poeschel.

Udéhn, L. (1993). Twenty-five years with the logic of collective action. Acta Sociologica, 36, 239-261.

Verband der Elektrizitätswirtschaft e.V. (VDEW) (2004). Strommarkt Deutschland. Zahlen und Fakten zur Stromversorgung. Frankfurt/Main: VDEW.

Von Weizsäcker, E. U., Young, O. R., \& Finger M. (2005). Limits to privatization. How to avoid too much of a good thing - a report to the Club of Rome. London: Earthscan.

Verbraucherzentrale Bundesverband (vzbv) (German Association of Consumer Organisations) (Ed.) (2005a). Kompromiss zulasten der Verbraucher. Verbraucherpolitische Korrespondenz, No. $6,15.3 .2005$, p. 6.

Verbraucherzentrale Bundesverband (vzbv) (German Association of Consumer Organisations) (Ed.) (2005b). Regierungsfraktionen sind jetzt in der Pflicht. Verbraucherpolitische Korrespondenz, No. 4, 15.2.2005, p. 2.

Weatherill, S. (2005). EU consumer law and policy. Cheltenham: Edward Elgar. 